\title{
Strategi keberlanjutan pengelolaan hutan larangan adat Kenegerian Rumbio Kabupaten Kampar Propinsi Riau
}

\author{
Budi Azwar $^{1 *}$, Defri Roza ${ }^{2}$, Husni Thamrin ${ }^{3}$, Elfiandri ${ }^{4}$ \\ 1,3,4 Universitas Islam Negeri Sultan Syarif Kasim Riau \\ Jalan HR. Soebrantas Panam KM. 15 No. 155. Sp. Panam Pekanbaru \\ ${ }^{2}$ Universitas Riau Kampus Bina Widya KM. 12.5 Sp. Panam Pekanbaru \\ *Koresponden E-mail: budiazwar@yahoo.com
}

(Diterima 27 Juni 2020|Disetujui 05 Januari 2021|Diterbitkan 30 Januari 2021)

\begin{abstract}
This study was carried out in the Kenegerian Rumbio customary forest area in Kampar Regency, Riau Province. The purpose of this study was to analyze priority strategic alternatives in sustainable management of Kenegerian Rumbio customary forest prohibitions in Kampar Regency. This research is descriptive research with quantitative research design. With the help of experts, FGD (focus group discussion) is carried out to obtain a priority hierarchy structure. Analysis method using AHP (analysis hierarchy process) technique. The research was conducted in the Area of Rumbio Kenegerian Customary Prohibition Forest Kampar Regency, Riau Province, starting from March to December 2019. The results of the study was identified that the alternative main priority strategy in the management of customary prohibited forests is the empowerment of forest area communities, following the subsequent strategy of strengthening traditional institutions. Furthermore alternative strategies for optimizing economic benefits and expanding cooperation networks. In the implementation of community empowerment strategies in forest areas, synergy between stakeholders in policies, programs, operational steps, goals, targets and targets of periodicity needs to be built.
\end{abstract}

Keywords: customary forests, strategy, empowerment, sustainability.

Paradigma pembangunan berkelanjutan telah menjadi basis konsep pembangunan hampir di sebagian besar negara-negara di dunia. Sejalan dengan itu, pemahaman tentang konsep pembangunan berkelanjutan mendapat tanggapan dari para ahli. Bond et al., (2001) menyatakan bahwa istilah keberlanjutan (sustainability) didefinisikan sebagai pembangunan dari kesepakatan multidimensional untuk mencapai kualitas hidup yang lebih baik untuk semua orang. Pemahaman lain terhadap konsep berkelanjutan dikemukakan oleh Roderic et al., (1997), bahwa berkelanjutan memerlukan pengelolaan tentang skala berkelanjutan ekonomi terhadap dukungan sistem ekologi, pembagian distribusi sumberdaya dan kesempatan antara generasi sekarang dan yang akan datang secara berimbang dan adil serta efisiensi dalam pengalokasian sumberdaya. Dilain kesempatan Dahuri et al., (1996) mengemukakan bahwa pembangunan berkelanjutan secara umum dapat dikelompokkan ke dalam empat dimensi yaitu ekologi, sosial ekonomi, sosial politik, serta hukum dan kelembagaan.

Sementara itu, hutan merupakan sumberdaya alam yang cukup potensial dan memiliki peran strategis dalam pembangunan. Dengan peran yang cukup strategis tersebut, konsep pengelolaan hutan di Indonesia bersifat dinamis, sesuai dengan kepentingan dan kebutuhan yang ingin dicapai. Fungsi hutan dalam pelayanan jasa lingkungan diberikan oleh keberadaan hutan sebagai penyerap karbon, perlindungan plasma nutfah, keanekaragaman hayati, dan nilai-nilai estetika yang potensial bernilai ekonomi apabila dapat dikelola dengan tepat. Hutan tidak hanya berkaitan dengan ekonomi perkayuan saja, tetapi amat jauh menjangkau berbagai sistem ekonomi, sosial dan budaya yang beranekaragam, yang juga merupakan potensi untuk mengembangkan berbagai bidang ilmu dan teknologi.
Pengertian keberlanjutan pengelolaan hutan bagi kelanjutan kehidupan lebih bijaksana jika tidak hanya memperhatikan pada kelestarian hasil saja, tetapi perlu memperhatikan aspek ekologi dan sosial ekonomi. Saat ini hutan telah berada pada keadaan yang sangat memprihatinkan. Banyak penyebab dari kerusakan hutan tersebut. Degradasi dan deforestasi merupakan permasalahan utama dalam mengembalikan dan menjaga kelestarian alam.

Salah satu tanah ulayat masyarakat adat Kenegerian Rumbio yang telah diakui oleh Pemerintah daerah Kabupaten Kampar adalah "ghimbo laghangan" atau hutan larangan atau hutan lindung. Hutan larangan ini adalah warisan turun temurun dan sudah ada sejak lama. Pada masa perjuangan kemerdekaan bangsa Indonesia, hutan larangan ini juga berfungsi sebagai tempat persembunyian dan perlindungan dari serangan penjajah Belanda dan Jepang. Tempat persembunyian berupa bentengbenteng masih dapat ditemukan saat ini dan berada di tengah hutan larangan. Menurut Dinas Kehutanan Kabupaten Kampar (2010), Hutan Larangan Adat Rumbio secara geografis terletak diantara $0^{\circ} 18^{\prime} 00^{\prime \prime}-0^{\circ}$ $19^{\prime} 40^{\prime \prime} \mathrm{LU}$ dan $101^{\circ} 7^{\prime} 00^{\prime \prime}-101^{\circ} 8^{\prime} 20^{\prime \prime}$ BT dengan luas 530 hektar.

Hutan Larangan Adat ini merupakan Pusako Tinggi masyarakat adat Kenegerian Rumbio, yang didalamnya tersimpan berbagai kekayaan alam serta flora dan fauna khas daerah ini. Di samping kekayaan flora dan fauna, ada kekayaan lain yang sangat bernilai bagi masyarakat adat Kenegerian Rumbio, yaitu fungsi hidroligis dan lingkungan dari hutan larangan adat tersebut, yaitu sebagai sumber mata air bersih yang langsung dapat diminum tanpa dimasak terlebih dahulu. Sebagian besar masyarakat Kenegerian Rumbio dan desa-desa di sekitarnya memperoleh air 
minum yang bersumber dari kaki bukit hutan larangan. Setiap hari ribuan liter air bersih diambil dari berbagai sumber mata air dan didistribusikan ke berbagai daerah, seperti Kampar, Bangkinang dan Pekanbaru. Air bersih itu juga mengairi puluhan hektar sawah dan ratusan petak kolam ikan di sekitar hutan larangan adat. Dalam menjaga kelestarian hutan larangan Adat Kenegerian Rumbio. Ninik mamak berperan penuh. Kebijakan-kebijakan adat dikeluarkan oleh sepuluh ninik mamak yang dipimpin oleh datuok Ulak Simano dari suku pitopang.

Keberlanjutan dan kelestarian hutan larangan adat Kenegerian Rumbio dimasa yang akan datang akan sangat bergantung dari partisipasi semua pihak (pemangku adat, pemerintah, alim ulama dan masyarakat) dapat terus menjaga dan melestarikan kearifan lokal yang telah ada dan dijalankan bertahun tahun lamanya dalam pengelolaan Hutan larangan Adat Rumbio demi kesejahteraan bersama masyarakat Rumbio baik saat ini maupun dimasa yang akan datang.

Penelitian ini bermaksud menganalisis alternatif strategis prioritas dalam pengelolaan hutan larangan adat kenegerian Rumbio di Kabupaten Kampar Propinsi Riau. Hasil penelitian diharapkan dapat menjadi salah satu pedoman dalam upaya menyusun langkah strategis yang harus dijalankan bagi pemangku kepentingan dalam mewujudkan sistem pengelolaan hutan larangan adat yang berkelanjutan.

\section{BAHAN DAN METODE}

Penelitian ini merupakan penelitian deskriptif dengan desain penelitian kuantitatif. Pendekatan kuantitatif deskriptif berusaha mengungkapkan fakta secara empiris. Rancangan penelitian dilakukan sesuai dengan tujuan penelitian yang akan dicapai yaitu untuk mendapatkan alternatif strategi yang tepat dan prioritas dalam pengelolaan hutan larangan adat kenegerian Rumbio dilakukan melalui FGD (focus group discussion) guna mendapatkan struktur hirarki terkait alternatif strategi yang tepat dan prioritas. Hal ini dianalisis menggunakan analisis deskriptif yang selanjutnya dijadikan bahan kuisioner guna diisi oleh para pakar sebagai bahan pembobotan alternatif strategi. Data yang diperoleh dianalisis dengan menggunakan AHP (analysis hierarchy process) untuk memperoleh alternatif strategi yang tepat dan prioritas.

\section{Lokasi Penelitian}

Penelitian dilaksanakan di kawasan Hutan Larangan Adat Kenegerian Rumbio Kabupaten
Kampar Propinsi Riau. Penelitian ini dilaksanakan sejak Maret sampai dengan Desember 2019, dengan subjek penelitian pengelola hutan adat, para pakar, serta masyarakat sekitar.

\section{Pengumpulan data}

Pengumpulan data dalam penelitian ini mencakup data primer data sekunder. Data primer adalah data yang diperoleh secara langsung di lapangan dari nara sumber, berupa hasil wawancara dan data kondisi eksisting pengelolaan hutan larangan adat di wilayah lokasi penelitian. Pengumpulan data primer dilakukan melalui survei lapangan, wawancara kepada pakar dan masyarakat. Wawancara dilakukan secara semi terstruktur dengan beberapa narasumber kunci dan pihak-pihak lain yaitu dari birokrat (kades), akademisi (kehutanan), praktisi, pemangku adat, tokoh masyarakat, dan LSM. Seterusnya dilakukan focus group discussion (FDG) dengan stakeholders pengelola hutan larangan adat kenegerian Rumbio (pemangku adat, Yayasan Pelopor Sehati SPKP, pemerintah, alim ulama dan masyarakat).

Data sekunder adalah data yang dikumpulkan melalui data statistik seperti data kependudukan, lingkungan, ekonomi dan sosial-budaya, hasil-hasil penelitian terdahulu atau laporan tahunan, dokumen perencanaan, regulasi, NSPM (norma, standard, pedoman dan manual), peta dan data hasil olahan lainnya serta instansi terkait. Instasi terkait tersebut antara lain Dinas Kehutanan, Yayasan Pelopor Sehati SPKP (Sentral Penyuluhan Kehutanan Pedesaan), Badan Pusat Statistik (BPS).

\section{Teknik Penentuan Responden}

Teknik penentuan responden dalam rangka mendapatkan dan menggali informasi dan pengetahuan dari para stakeholder dan pakar adalah dengan menggunakan metode expert survey dengan melakukan wawancara mendalam (indepth interview) dengan responden yang telah ditentukan/dipilih secara sengaja (purposive sampling).Kriteria untuk memenuhi syarat sebagai pakar adalah (Marimin 2004): 1). Seseorang yang mendapat pendidikan formal S2/S3 pada bidang yang dikaji. 2). Seseorang yang berpengalaman pada bidang yang dikaji (minimal 10 tahun), tetapi memiliki pendidikan formal di bidang lain. 3). Seseorang yang berpendidikan formal dan berpengalaman pada bidang yang dikaji, minimal 5 tahun.

Seseorang yang berasal dari praktisi, didasarkan pada lama kerja dan kewenangan di suatu posisi tertentu (minimal 5 tahun). Kalangan pakar dan jumlahnya dapat dilihat pada Tabel 1. 
Tabel 1. Jumlah pakar yang dilih sebagai responden

\begin{tabular}{ccc}
\hline No & Pakar & Jumlah \\
\hline 1 & Birokrat : Kades & 1 \\
2 & Akademisi (Pakar Kehutanan) & 2 \\
3 & Praktisi & 1 \\
4 & Pemangku adat & 1 \\
5 & Tokoh Masyarakat & 1 \\
6 & LSM & 1 \\
\hline & Total & 7 \\
\hline
\end{tabular}

\section{Analisis Data}

Analisis data yang digunakan analytical hierarchy process (AHP) guna mendapatkan alternatif arah kebijakan. Analitical hierarchy process (AHP) merupakan suatu model pendukung keputusan yang dikembangkan oleh Thomas L.Saaty. Model ini akan menguraikan masalah multi faktor ataupun multi kriteria yang kompleks menjadi suatu hirarki. Menurut Saaty (2008), hirarki didefinisikan sebagai suatu representasi dari sebuah permasalahan yang kompleks dalam suatu struktur multi level di mana level pertama adalah tujuan/fokus, yang diikuti level faktor, kriteria, sub kriteria, dan seterusnya ke bawah hingga level terakhir dari alternatif. Menurut Marimin (2004), AHP memiliki banyak keunggulan dalam menjelaskan proses pengambilan keputusan, karena dapat digambarkan secara grafis, sehingga mudah dipahami oleh semua pihak yang terlibat dalam pengambilan keputusan. Skala penilaian kriteria berbasis pada penilaian pakar dengan menggunakan metode perbandingan berpasangan (pairwise comparison) yang dikembangkan oleh Thomas L.Saaty (Marimin, 2004). Skala penilaian perbandingan berpasangan seperti disajikan pada Tabel

Tabel 2. Skala penilaian

\begin{tabular}{cl}
\hline Skala & \multicolumn{1}{c}{ Keterangan } \\
\hline 1 & Kedua elemen sama pentingnya \\
3 & Elemen yang satu sedikit lebih penting dari elemen yang lain \\
5 & Elemen yang satu lebih penting dari elemen yang lain \\
7 & Elemen yang satu jelas lebih penting dari elemen yang lain \\
9 & Elemen yang satu mutlak penting dari elemen yang lain \\
$2,4,6,8$ & Nilai-nilai diantara kedua nilai pertimbangan yang berdekatan \\
\hline
\end{tabular}
Sumber: Saaty, 2008.

\section{HASIL}

Level pertama dalam struktur hirarki AHP adalah sasaran yang ingin dicapai. Sasaran dari permasalahan yang diangkat dalam penelitian ini adalah menentukan strategi pengelolaan hutan larangan adat kenegerian Rumbio yang berkelanjutan. Agar dapat meraih sasaran tersebut, pendekatan rantai nilai digunakan untuk mengidentifikasi dimensi apa saja paling menentukan serta indikator dari masingmasing dimensi yang paling berpengaruh dalam penentuan model pengelolaan hutan adat yang berkelanjutan.

Beberapa alternatif strategis prioritas yang ditawarkan untuk mencapai sasaran tujuan strategi pengelolaan hutan larangan adat kenegerian Rumbio ini adalah penguatan kelembagaan adat, optimalisasi manfaat ekonomi, pemberdayaan masyarakat di kawasan hutan, dan perluasan jejaring (networks) kerjasama. Setiap alternatif strategi terdapat indikatorindikator penting dalam dimensi ekologi, ekonomi, sosial budaya, dan hukum kelembagaan yakni indikator biodiversiti, ketersediaan bibit, potensi wisata, penduduk miskin, anggaran pemerintah, manajen konflik, praktek budaya local, kapasitas kelembagaan, dan keterlibatan lembaga masyarakat.

Perumusan strategi rencana pengelolaan kawasan hutan larangan adat kenegerian Rumbio disusun berdasarkan data yang diperoleh melalui tiga metode penggalian data, yakni observasi lapangan, wawancara mendalam terhadap informan kunci dari stakeholder yang terkait baik langsung maupun tidak langsung dalam pengelolaan hutan larangan adat, dan FGD yang dilakukan untuk mendapatkan alternatif strategiprioritas dalam pengelolaan hutan larangan adat Kenegerian Rumbio. Hirarki keterkaitan antar bagian dalam pemilihan strategi pengelolaan hutan larangan adat kenegerian Rumbio, dapat dilihat pada Gambar 1.berikut ini. 


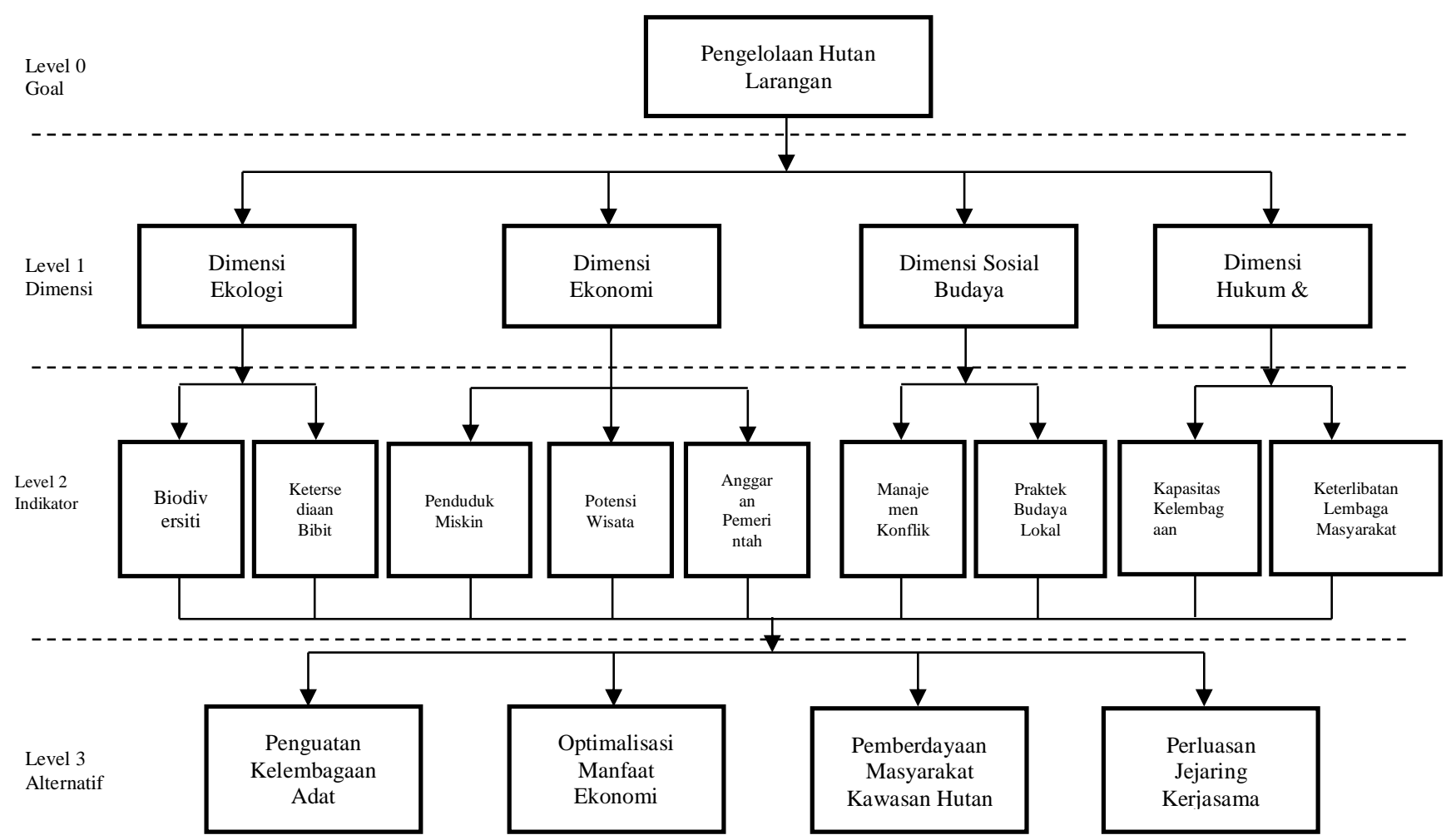

Gambar 1. strategi pengelolaan hutan larangan adat kenegerian Rumbio

\section{Skala Prioritas Alternatif Strategi}

Dalam upaya untuk mencapai tujuan pengelolaan hutan adat yang berkelanjutan, maka ada empat alternatif strategi prioritas yang ditawarkan untuk dapat dilaksanakan sesuai dengan tujuan pengelolaan hutan adat Rumbio sebagaimana tertuang dalam masterplan hutan larangan adat Rumbio oleh Bappeda Kabupaten Kampar (Insusanty \& Sadjati, 2015), yakni penguatan kelembagaan adat, optimalisasi manfaat ekonomi, pemberdayaan masyarakat kawasan hutan, dan perluasan jejaring kerjasama (netwoks). Berikut dapat disajikan nilai bobot dari alternatif dilihat dari keterkaitanya dengan setiap indikator yang ada.
Melalui Tabel 3 berikut dapat diketahui bahwa, alternatif strategi yang menjadi prioritas utama didalam pencapaian pengelolaan hutan adat yang berkelanjutan adalah strategi pemberdayaan masyarakat di kawasan hutan, dengan nilai bobot sebesar $42,3 \%$. Konsen berikutnya yang memiliki andil cukup penting dan perlu menjadi prioritas utama kedua adalah strategi penguatan kelembagaan adat dengan nilai bobot $29,1 \%$, dan seterusnya dikuti alternatif strategi optimalisasi manfaat ekonomi dan perluasan jejaring kerjasama, dengan nilai bobot masing-masing sebesar $15,5 \%$ dan $13,1 \%$.

Tabel 3. Skala Prioritas Alternatif Strategi

\begin{tabular}{|c|c|c|c|c|c|c|c|c|c|c|}
\hline \multirow{3}{*}{ Dimensi } & \multirow{3}{*}{ Indikator } & \multirow{3}{*}{$\begin{array}{c}\text { Bobot } \\
\text { Indikator }\end{array}$} & \multicolumn{8}{|c|}{ Alternatif } \\
\hline & & & \multicolumn{2}{|c|}{ PKA } & \multicolumn{2}{|c|}{ OME } & \multicolumn{2}{|c|}{ PMKH } & \multicolumn{2}{|c|}{ PJK } \\
\hline & & & $\begin{array}{l}\text { Bobot } \\
\text { Lokal }\end{array}$ & $\begin{array}{c}\text { Bobot } \\
\text { Gabungan }\end{array}$ & $\begin{array}{l}\text { Bobot } \\
\text { Lokal }\end{array}$ & $\begin{array}{c}\text { Bobot } \\
\text { Gabungan }\end{array}$ & $\begin{array}{l}\text { Bobot } \\
\text { Lokal }\end{array}$ & $\begin{array}{c}\text { Bobot } \\
\text { Gabungan }\end{array}$ & $\begin{array}{l}\text { Bobot } \\
\text { Lokal }\end{array}$ & $\begin{array}{c}\text { Bobot } \\
\text { Gabungan }\end{array}$ \\
\hline \multirow{2}{*}{ Ekologi } & Biod & $42.7 \%$ & $21.0 \%$ & $9.0 \%$ & $11.2 \%$ & $4.8 \%$ & $54.3 \%$ & $23.2 \%$ & $13.5 \%$ & $5.8 \%$ \\
\hline & $\mathrm{KB}$ & $7.0 \%$ & $8.7 \%$ & $0.6 \%$ & $24.9 \%$ & $1.7 \%$ & $51.5 \%$ & $3.6 \%$ & $14.8 \%$ & $1.0 \%$ \\
\hline \multirow{3}{*}{ Ekonomi } & PM & $7.2 \%$ & $8.5 \%$ & $0.6 \%$ & $37.4 \%$ & $2.7 \%$ & $38.1 \%$ & $2.8 \%$ & $16.0 \%$ & $1.2 \%$ \\
\hline & PW & $4.4 \%$ & $16.5 \%$ & $0.7 \%$ & $25.0 \%$ & $1.1 \%$ & $35.6 \%$ & $1.6 \%$ & $22.9 \%$ & $1.0 \%$ \\
\hline & $\mathrm{AP}$ & $2.3 \%$ & $17.4 \%$ & $0.4 \%$ & $38.4 \%$ & $0.9 \%$ & $31.3 \%$ & $0.7 \%$ & $12.9 \%$ & $0.3 \%$ \\
\hline \multirow{2}{*}{ Sosbud } & MK & $8.5 \%$ & $53.6 \%$ & $4.6 \%$ & $16.0 \%$ & $1.4 \%$ & $23.0 \%$ & $2.0 \%$ & $7.4 \%$ & $0.6 \%$ \\
\hline & PBL & $5.9 \%$ & $37.5 \%$ & $2.2 \%$ & $10.6 \%$ & $0.6 \%$ & $36.1 \%$ & $2.1 \%$ & $15.8 \%$ & $0.9 \%$ \\
\hline \multirow{4}{*}{$\begin{array}{c}\text { Hukum \& } \\
\text { Kelembagaan }\end{array}$} & KK & $10.5 \%$ & $58.4 \%$ & $6.1 \%$ & $9.1 \%$ & $1.0 \%$ & $22.6 \%$ & $2.4 \%$ & $10.0 \%$ & $1.0 \%$ \\
\hline & KLM & $11.4 \%$ & $43.0 \%$ & $4.9 \%$ & $11.8 \%$ & $1.4 \%$ & $34.7 \%$ & $4.0 \%$ & $10.5 \%$ & $1.2 \%$ \\
\hline & & & $\begin{array}{l}\text { Bobot } \\
\text { PKA }\end{array}$ & $29.1 \%$ & $\begin{array}{l}\text { Bobot } \\
\text { OME }\end{array}$ & $15.5 \%$ & $\begin{array}{l}\text { Bobot } \\
\text { PMKH }\end{array}$ & $42.3 \%$ & $\begin{array}{l}\text { Bobot } \\
\text { PJK }\end{array}$ & $13.1 \%$ \\
\hline & Prioritas & & & 2 & & 3 & & 1 & & 4 \\
\hline
\end{tabular}

Keterangan:

PKA= Penguatan Kelembagaan Adat, OME= Optimalisasi Manfaat Ekonomi, PMKH= Pemberdayaan Masyarakat Kawasan Hutan, PJK=

Perluasan Jejaring Kerjasama 
Dari hasil pengukuran bobot gabungan yang telah dilakukan, juga dapat gambarkan nilai bobot dari masing-masing alternatif strategis yang menjadi prioritas, seperti terlihat dalam Gambar 2 berikut.

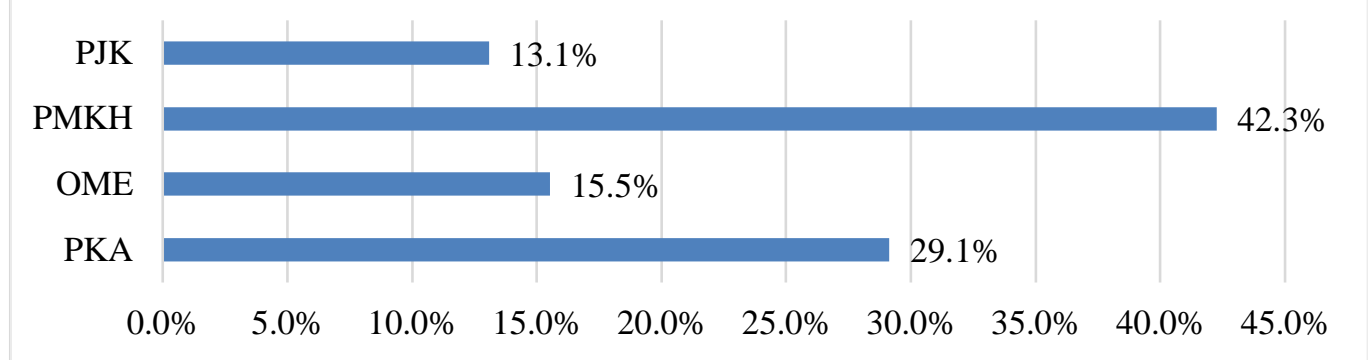

Gambar 2. Grafik Nilai Bobot Alternatif Strategi Prioritas

Berdasarkan penilaian-penilaian yang telah dilakukan terhadap setiap dimensi, dan indikator, telah diketahui bahwa alternatif strategi yang menjadi prioritas utama dan layak dikedepankan dalam keputusan pengelolaan hutan larangan adat kenegerian Rumbio secara berkelanjutan adalah strategi pemberdayaan masyarakat di kawasan hutan dengan bobot penilaian 42,3\%. Alternatif strategi prioritas kedua yaitu penguatan kelembagaan adat dengan bobot penilaian $29,1 \%$. Strategi optimalisasi manfaat ekonomi dapat dijadikan alternatif kegiatan bagi peningkatan nilai ekonomi kawasan hutan larangan adat untuk mendukung kegiatan potensi wisata, pengurangan penduduk miskin dengan menambah anggaran pemerintah. Perluasan jejaring kerjasama dengan berbagai pihak dapat dijadikan strategi pendukung berikutnya bagi menjaga keberlanjutan hutan larangan adat kenegerian Rumbio.

\section{PEMBAHASAN}

Ketika kondisi kawasan hutan mengalami kerusakan yang mengkhawatirkan dan belum dapat direhabilitasi dan dijaga dengan baik serta telah menjadi permasalahan global, maka pelestarian hutan yang dilakukan secara swadaya oleh masyarakat atau kelompok masyarakat menjadi suatu hal yang sangat menarik.

Agar tata lingkungan hidup terjamin kelestariannya, maka pengurusan hutan yang berkelanjutan harus menampung dinamika aspirasi dan peran serta masyarakat, adat dan budaya, serta tata nilai masyarakat berdasarkan pada norma hukum lokal dan nasional agar pendayagunaannya dilakukan seoptimal mungkin bagi kesejahteraan umat manusia. Paradigma baru pembangunan kehutanan saat ini menekankan bahwa hutan harus dipandang sebagai sumber daya secara komprehensif dengan menitik beratkan pada pembangunan kehutanan bersama masyarakat (community development). Salah satu pendekatan pembangunan kehutanan adalah melibatkan partisipasi masyarakat. Dalam perspektif lingkungan ini, melibatkan partisipasi masyarakat mengacu pada pengamanan akses terhadap sumberdaya alam dan pengelolaannya secara berkelanjutan (Riyanto, 2005).
Strategi Prioritas Bagi Keberlanjutan Pengelolaan Hutan Adat Rumbio

Berdasarkan penilaian-penilaian yang telah dilakukan terhadap setiap dimensi dan aspek, dan indikator dan faktor, telah diketahui bahwa alternatif strategi yang menjadi prioritas utama dan layak dikedepankan, serta mendapat porsi yang besar dalam keputusan pengelolaan hutan larangan adat kenegerian Rumbio secara berkelanjutan adalah strategi pemberdayaan masyarakat di kawasan hutan tersebut. Kajian Theresia et al., (2015), mendapatkan juga bahwa alternatif strategi pengelolaan ekosistem mangrov yang menjadi prioritas utama ialah pemberdayaan masyarakat yang bisa memiliki keterampilan dalam pemanfaatan mangrov yang lestari.

Paradigma baru pembangunan kehutanan saat ini menekankan bahwa hutan harus dipandang sebagai sumber daya secara komprehensif dengan menitik beratkan pada pembangunan kehutanan bersama masyarakat (community development). Dengan demikian salah satu pendekatan pembangunan kehutanan adalah melibatkan partisipasi masyarakat.

Menyimak bahwa pemberdayaan masyarakat merupakan konsep pembangunan ekonomi yang merangkum nilai-nilai sosial yang merupakan cermin dari pradigma baru pembangunan kehutanan yang bersifat "people centered, participatory, empowering, and sustainable". Tujuan akhir dari proses pemberdayaan masyarakat adalah untuk memandirikan warga masyarakat agar dapat meningkatkan taraf hidup keluarga dan mengoptimalkan sumber daya yang dimilikinya. Daya, kekuatan dan kemampuan yang dimiliki masyarakat secara memadai akan mendorong masyarakat untuk dapat mengakses sumbersumberdaya produktif, mandiri dalam pengambilan keputusan dan percaya diri dalam bertindak.

Dalam perspektif lingkungan, pemberdayaan mengacu pada pengamanan akses terhadap sumberdaya alam dan pengelolaannya secara berkelanjutan (Riyanto, 2005). Selama ini pemberdayaan dimaknai sempit oleh berbagai pihak, sehingga pendekatan pemberdayaan diterjemahkan terbatas pada bantuan yang bersifat material (Herawati, 2012). Pendekatan pemberdayaan yang bersifat dimana masyarakat dianggap sebagai obyek, terbukti tidak mampu memberdayakan masyarakat, masyarakat tidak menjadi mandiri tetapi justru 
tergantung pada program-program pemberdayaan. Idealnya pemberdayaan mampu mengubah sasaran baik secara individu, kelompok maupun masyarakat dari kondisi tidak berdaya ke kondisi berdaya dan bermuara pada kondisi mandiri (Sumardjo, 2012). Masyarakat desa hutan yang sejahtera adalah masyarakat yang mandiri dan mampu berfungsi meningkatkan kesejahteraannya, memelihara ketertiban sosial dan kelestarian lingkungannya (Effendi, 2007).

Sebagai masyarakat yang tinggal di sekitar kawasan hutan adat, kemandirian dalam mengembangkan perilaku di bidang ekologi sangat penting. Pada umumnya masyarakat mengetahui bahwa hutan adat adalah merupakan kawasan yang dilindungi.

Interaksi dan akses masyarakat terhadap hutan adat merupakan faktor penting dalam mengukur dampak pemberdayaan. Hal ini berkaitan dengan bagaimana kecenderungan perubahan dalam masyarakat yang tinggal disekitar kawasan dan sebagian besar berbatasan langsung dan berinteraksi dengan kawasan, sebagai hasil/dampak kegiatan pemberdayaan dalam pemenuhan kebutuhan hidupnya. Interaksi positif dan akses bagi masyarakat dalam zona tertentu hutan larangan adat diharapkan dapat meningkatkan kemandirian mereka.

Tuntutan pemenuhan kebutuhan dan keterbatasan lahan menyebabkan masyarakat memanfaatkan kawasan hutan. Dengan adanya kegiatan pemberdayaan dan seiring kesadaran masyarakat yang semakin baik, saat ini aktifitas tersebut sudah berkurang, meskipun berbagai aktifitas lain untuk memenuhi kebutuhan masih dilakukan, antara lain mengambil berbagai hasil hutan untuk memenuhi kebutuhan mulai dari kebutuhan akan air, pakan ternak, kayu bakar, berburu, tanaman obat. Manfaat langsung keberadaan hutan adat yang dirasakan oleh masyarakat sangat kuat. Manfaat langsung yang dirasakan ini berkorelasi positif dengan kemandirian. Hal ini berarti semakin besar manfaat langsung yang dirasakan, maka diharapkan masyarakat akan semakin terdorong untuk mengembangkan perilaku kemandirian.

Manfaat hutan adat terdiri dari manfaat ekonomi, ekologi dan sosial budaya. Namun demikian, sebagaimana di ketahui bahwa kebutuhan masyarakat di sekitar kawasan adat adalah kebutuhan untuk waktu sekarang. Berdasarkan hal tersebut, upaya untuk meningkatkan manfaat langsung yang dirasakan masyarakat dengan adanya hutan adat perlu dipertimbangkan dalam pengelolaannya, sehingga terjadi interaksi positif antara masyarakat dengan kawasan.

Strategi pengembangan pemberdayaan masyarakat disekitar kawasan hutan adat Rumbio yang dapat dikembangkan adalah: menyempurnakan proses pemberdayaan dengan meningkatkan keterlibatan masyarakat dalam tahapan proses pemberdayaan, meningkatkan kemampuan pelaku pemberdayaan, terutama terkait dengan ketrampilan dan sikap keberpihakan pada masyarakat dan penguatan modal sosial masyarakat.

Untuk meningkatkan kemampuan pelaku pemberdayaan masyarakat dapat dilakukan melalui kegiatan pelatihan, kursus, seminar dan lain sebagainya, sedangkan untuk menguatkan kapasitas masyarakat kawasan hutan dapat dilakukan melalui kegiatan penyuluhan, pendampingan dan pelibatan masyarakat dalam proses pemberdayaan secara optimal dengan tujuan untuk menumbuhkan kesadaran akan pentingnya kerjasama, saling percaya, mentaati norma, kepedulian terhadap sesama dan keikutsertaan dalam aktivitas organisasi sosial masyarakat. Sedangkan materi pemberdayaan masyarakat sekitar kawasan hutan yang dapat dikembangkan diantaranya adalah peningkatan produktivitas perikanan rakyat peningkatan produktivitas pertanian rakyat, peningkatan produktivitas dan daya saing perkebunan rakyat, peningkatan kemampuan masyarakat terhadap usaha peternakan rakyat, dan peningkatan kemampuan kerajinan rakyat.

Pemberdayaan masyarakat daerah penyangga sekitar hutan adat Rumbio tidak hanya untuk meminimalisir terjadinya kerusakan sumberdaya hutan dan ekosistemnya akibat perambahan dan tindak illegal lainnya namun juga diarahkan sebagai upaya untuk memberikan kesempatan, kemudahan dan fasilitasi pada masyarakat agar secara mandiri tau, sadar, mau dan mampu mengembangkan potensi yang dimiliki dengan senantiasa memperhatikan upaya pelestarian sumberdaya alam dan lingkungan hidupnya.

Kelembagaan adat juga mempunyai posisi penting dan kuat dalam aturan-aturan main yang jelas dalam pengelolaan hutan adat melalui indikator penglibatan kelembagaan masyarakat yang mendukung. Kelembagaan masyarakat yang dimaksud antara lain yayasan pelopor, sentra penyuluh terpadu kehutanan, dan kelompok sadar wisata.

Dalam kegiatan pemberdayaan, dimana kawasan hutan yang berhamparan langsung dengan usaha-usaha ekonomi masyarakat terutama perkebunan dan juga tidak jauh dari daerah pemukiman masyarakat mempunyai kompleksitas permasalahan hutan dengan masyarakat sendiri, maka diharapkan dalam pelaksanaannya mendapat dukungan bukan saja dari kelembagaan adat yang meletakkan aturan-aturan main tetapi juga dari lembaga masyarakat adat yang terkait dengan kegiatan pemberdayaan. Peran penyuluh dalam hal ini sentra penyuluh kehutanan sebagai fasilitator mata rantai komunikasi yang menghubungkan keberadaan hutan adat dengan masyarakat itu sendiri. Dalam konteks ini berkaitan dengan kemampuan yang dimiliki fasilitator, meliputi kedekatan dengan masyarakat, kemampuan dalam membangun kesepakatan bersama, mengembangkan hubungan dan membangun kemitraan, memberikan saran, masukan dan informasi bermanfaat serta keterampilan teknis yang dimiliki.

Bentuk kegiatan pemberdayaan mempunyai hubungan yang kuat dengan kemandirian masyarakat. 
Dalam konteks penelitian ini, bentuk kegiatan pemberdayaan yang seimbang dalam bentuk fisik, didukung oleh peningkatan kapasitas sesuai dengan kebutuhan masyarakat, penguatan kelembagaan, dan penguatan jaringan kemitraan serta monitoring dan evaluasi sesuai dengan yang dibutuhkan masyarakat sasaran serta kondisi lokal setempat diharapkan dapat mendukung keberhasilan pemberdayaan. Oleh karena itu, upaya pemberdayaan masyarakat merupakan salah satu alternatif untuk mengangkat harkat dan martabat masyarakat disekitar kawasan hutan adat Rumbio secara berkelanjutan.

Lengkapnya langkah-langkah operasional yang dapat dilakukan pada strategi prioritas pemberdayaan masyarakat di kawasan hutan sebagai strategi alternative dan keterlibatan actor penting utama dalam menentukan keberlanjutan pengelolaan hutan larangan adat Kenegerian Rumbio dapat dilihat pada Tabel 4.

Tabel 4. Langkah Operasional Strategi Pemberdayaan Masyarakat Kawasan HutanAdat Rumbio

\begin{tabular}{|c|c|c|c|}
\hline Target Operasional & Langkah Operasional & Indikasi Program & $\begin{array}{l}\text { Keterlibatan } \\
\text { Stakeholder }\end{array}$ \\
\hline \multirow[t]{5}{*}{$\begin{array}{l}\text { 1. Meningkatkan } \\
\text { kapasitas } \\
\text { masyarakat agar } \\
\text { dapat berperan } \\
\text { aktif dalam } \\
\text { pengelolaan hutan }\end{array}$} & $\begin{array}{l}\text { a. Dilaksanakannya need } \\
\text { assessment untuk } \\
\text { mengetahui } \\
\text { kebutuhan-kebutuhan } \\
\text { kapasitasi masyarakat }\end{array}$ & $\begin{array}{l}\text { - Need assessment } \\
\text { kebutuhan- } \\
\text { kebutuhan } \\
\text { kapasitas } \\
\text { masyarakat }\end{array}$ & $\begin{array}{l}\text { - DiskopUKM } \\
\text { - Pemdes } \\
\text { - Dinas PMD } \\
\text { - Kelompok swadaya }\end{array}$ \\
\hline & $\begin{array}{l}\text { b. Dilaksanakannya } \\
\text { kapasitasi masyarakat } \\
\text { di bidang-bidang yang } \\
\text { mendukung } \\
\text { pelaksanaan fungsi }\end{array}$ & $\begin{array}{l}\text { - Pelatihan di } \\
\text { bidang-bidang yang } \\
\text { mendukung } \\
\text { pelaksanaan fungsi } \\
\text { hutan pendidikan }\end{array}$ & $\begin{array}{l}\text { - Dinas Pendidikan } \\
\text { - DLH } \\
\text { - Kelompok Swadaya }\end{array}$ \\
\hline & $\begin{array}{l}\text { hutan pendidikan, } \\
\text { sebagai pegiat } \\
\text { ekowisata serta pegiat } \\
\text { wisata adat, dan } \\
\text { HHBK }\end{array}$ & $\begin{array}{l}\text { - Pelatihan pegiat } \\
\text { ekowisata } \\
\text { - Pelatihan } \\
\text { optimalisasi HHBK }\end{array}$ & $\begin{array}{l}\text { - Dinas Pariwisata } \\
\text { - Kelompok Swadaya } \\
\text { - Dinas Kehutanan } \\
\text { - DLH }\end{array}$ \\
\hline & $\begin{array}{l}\text { c. Dilaksanakannya } \\
\text { kapasitasi masyarakat } \\
\text { di bidang pengawasan } \\
\text { dan konservasi sumber } \\
\text { daya hutan }\end{array}$ & $\begin{array}{l}\text { - Pelatihan } \\
\text { pengawasan dan } \\
\text { konservasi sumber } \\
\text { daya hutan }\end{array}$ & $\begin{array}{l}\text { - DLH } \\
\text { - Dinas Kehutanan }\end{array}$ \\
\hline & $\begin{array}{l}\text { d. Tersedianya } \\
\text { kebutuhan pendukung } \\
\text { bagi masyarakat untuk } \\
\text { mempraktekkan } \\
\text { kapasitasi yang } \\
\text { diberikan }\end{array}$ & 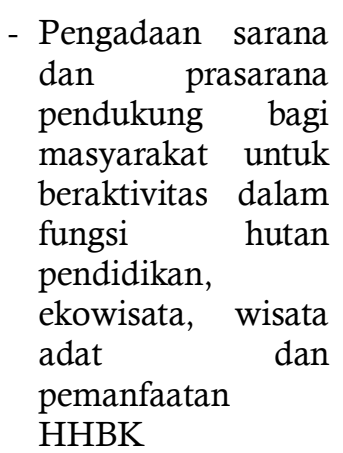 & $\begin{array}{l}\text { - Dinas Pendidikan } \\
\text { - Dinas Pariwisata } \\
\text { - DLH } \\
\text { - Dinas Kehutanan }\end{array}$ \\
\hline \multirow[t]{2}{*}{$\begin{array}{l}\text { 2. Melaksanakan } \\
\text { pendampingan } \\
\text { bagi usaha-usaha } \\
\text { masyarakat yang } \\
\text { berbasis hutan dan } \\
\text { lestari }\end{array}$} & $\begin{array}{l}\text { a. Disediakannya } \\
\text { dukungan-dukungan } \\
\text { yang bersifat stimulan } \\
\text { untuk masyarakat } \\
\text { menjalankan usaha- } \\
\text { usaha yang berbasis } \\
\text { hutan dan lestari }\end{array}$ & 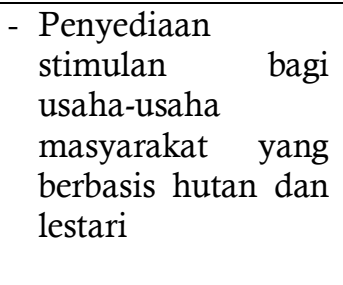 & $\begin{array}{l}\text { - Dinas Sosial } \\
\text { - Dinas Koperasi dan } \\
\text { UMKM } \\
\text { - Dinas Kehutanan } \\
\text { - DLH }\end{array}$ \\
\hline & $\begin{array}{lr}\text { b. Adanya tim } \\
\text { pendamping dari } \\
\text { berbagai pihak yang } \\
\begin{array}{l}\text { berkompeten dan } \\
\text { berkomitmen jangka } \\
\text { panjang }\end{array}\end{array}$ & $\begin{array}{l}\text { - Kerjasama } \\
\text { pendampingan } \\
\text { masyarakat oleh } \\
\text { tenaga ahli }\end{array}$ & $\begin{array}{l}\text { - Dinas Kehutanan } \\
\text { - Dinas Koperasi } \\
\text { - Dinas PMD } \\
\text { - DLH }\end{array}$ \\
\hline
\end{tabular}




\section{SIMPULAN}

Alternatif strategi prioritas utama dalam pengelolaan hutan larangan adat adalah pemberdayaan masyarakat kawasan hutan, menyusul berikutnya strategi penguatan kelembagaan adat. Seterusnya alternatif strategi optimalisasi manfaat ekonomi dan perluasan jejaring kerjasama. Dalam implementasi strategi pemberdayaan masyarakat di kawasan hutan perlu dibangun sinerginitas antar pemangku kepentingan dalam kebijakan, program, langkah operasional, tujuan, sasaran dan target-target periodesasi.

\section{UCAPAN TERIMA KASIH}

Penulis mengucapkan terima kasih atas bantuan berbagai pihak yang telah memberikan dukungan terhadap penelitian ini.

\section{DAFTAR PUSTAKA}

Bond, Richard, Curan, Jahanna, Kirk Patrick, Lece, Norman, Francis, Paul. (2001). Integrated Impact Assessment for Sustainable Development, A Case Study Approach, University of Manchester, UK.

Dahuri, R., Rais, J., Ginting, S.P., SItepu, M.J. (1996). Pengelolaan Sumberdaya Pesisir dan Lautan Secara Terpadu, Pradnya Paramita, IPB.

Dinas Kehutanan Kabupaten Kampar. (2010). Buku Data Kehutanan Kabupaten Kampar. Riau.

Effendi, R., Bangsawan, I., Muttaqin, M.Z. (2007). Kajian Pola-Pola Pemberdayaan Masyarakat Sekitar Hutan Produksi dalam Mencegah Illegal Logging. Jurnal Penelitian Sosial danEkonomi Kehutanan 4(4):321- 340. https://doi.org/10.20886/jpsek.2007.4.4.321-340

Herawati,T.(2012).Manajemen umberdayaKeluarga dan Ketahanan Keluarga Peserta Pemberdayaan Masyarkat di Pedesaan (Kasusdi Kabupaten Bogor) [disertasi]. Bogor: Sekolah Pascasarjana, Institut Pertanian Bogor.
Insusanty \& Sadjati. (2015). Masterplan Hutan Larangan Adat Kenegerian Rumbio dan Hutan Adat buluh Cina Kabupaten Kampar Provinsi Riau.Kerjasama Badan Perencanaan Daerah Kabupaten Kampar Provinsi Riau dengan Pusat Pengkajian Perencanaan dan Pengembangan Wilayah (P4w) Lembaga Penelitian Dan Pengabdian Masyarakat (LPPM) Institut Pertanian Bogor.

Roderic, G., Meppem, Tony. (1997). Planning for Sustainability as a Learning Concepts, New England Ecological Economic Group, Center for Water Policy Reseacrh, University of New England, Armidale, Australia.

Marimin. (2004). Teknik dan Aplikasi Pengambilan Keputusan Kriteri Majemuk. Jakarta (ID): PT. Grasindo.

Riyanto,B. (2005). Pemberdayaan Masyarakat Sekitar Hutan dalam Perlindungan Kawasan Pelestarian Alam. Bogor: Lembaga Pengkajian Hukum Kehutanan dan Lingkungan.

Sumardjo. (2012). Review dan Refleksi Model Penyuluhan dan Inovasi Penyuluhan Masa Depan [makalah]. Seminar Nasional Membangun Penyuluhan Masa Depan yang Berkeadilan dan Menyejahterakan, 20 Februari 2012. Bogor: Ilmu Penyuluhan Pembangunan, Sekolah Pascasarjana, Institut Pertanian Bogor.

Saaty, T. L. (2008). Pengambilan Keputusan Bagi Para Pemimpin : Proses Hirarki Analitik untuk Pengambilan Keputusan dalam Situasi yang Kompleks terjemahan Decisions Making for Leaders : The Analytical

Theresia, Mennofatria B, Niken T.M.P. (2015). Status Keberlanjutan Pengelolaan Ekosistem Mangrove di Taman Nasional Sembilang Kabupaten Banyuasin Provinsi Sumatera Selatan. Jurnal Ilmu dan Teknologi Kelautan Tropis, 7(2): 703-714. https://doi.org/10.29244/jitkt.v7i2.11120 